\title{
Unfolding trends of COVID-19 transmission in India: Critical review of available Mathematical models
}

\section{Komal Shah, Ashish Awasthi, Bhavesh Modi, Rashmi Kundapur, Deepak B Saxena}

${ }^{1}$ Assistant Professor, Indian Institute of Public Health Gandhinagar, Gandhinagar; ${ }^{2}$ Assistant Professor, Public Health Foundation of India, Gurgaon; ${ }^{3}$ Associate Professor, Department of Community Medicine, GMERS Medical College, Gandhinagar, Gujarat; ${ }^{4}$ Professor of Community Medicine, Department of Community Medicine, K.S. Hegde Medical Academy, Nitte University, Mangalore: 576018; ${ }^{5}$ Professor, Indian Institute of Public Health Gandhinagar, Gandhinagar

\section{$\underline{\text { Abstract }} \underline{\text { Introduction }}$ Methodology $\underline{\text { Results }}$ Conclusion $\underline{\text { References }}$ Citation $\underline{\text { Tables / Figures }}$ \\ Corresponding Author}

Dr Deepak B Saxena, Professor, IIPH Gandhinagar-Gandhinagar

E Mail ID: ddeepak72@iiphg.org

\section{Citation}

Shah K, Awasthi A, Modi B, Kundapur R, Saxena DB. Unfolding trends of COVID-19 transmission in India: Critical review of available Mathematical models. Indian J Comm Health. 2020;32(2-Special Issue):206-214.

Source of Funding: Ashish Awasthi is supported by the Department of Science and Technology, Government of India, New Delhi through INSPIRE Faculty program. No financial assistance was received in support of this study. Conflict of Interest: None declared

\section{Article Cycle}

Received: 12/04/2020 Revision: 15/04/2020; Accepted: 20/04/2020; Published: 20/04/2020

This work is licensed under a Creative Commons Attribution 4.0 International License.

\section{Abstract}

Background: There is a surge in epidemiological modeling research due to sudden onset of COVID-19 pandemic across the globe. In the absence of any pharmaceutical interventions to control the epidemic, nonpharmaceutical interventions like containment, mitigation and suppression are tried and tested partners in epidemiological theories. But policy and planning needs estimates of disease burden in various scenarios in absence of real data and epidemiological models helps to fill this gap. Aims and Objectives: To review the models of COVID-19 prediction in Indian scenario, critically evaluate the range, concepts, strength and limitations of these prediction models and its potential policy implications. Results: Though we conducted data search for last three months, it was found that the predictive models reporting from Indian context have started publishing very recently. Majority of the Indian models predicted COVID-19 spread, projected best-, worst case scenario and forecasted effect of various preventive measurements such as lockdown and social distancing. Though the models provided some of the critical information regarding spread of the disease and fatality rate associated with COVID-19, it should be used with caution due to severe data gaps, distinct socio-demographic profiling of the population and diverse statistics of co-morbid condition. Conclusion: Although the models were designed to predict COVID spread, and claimed to be accurate, significant data gaps and need for adjust confounding variables such as effect of lockdown, risk factors and adherence to social distancing should be considered before generalizing the findings. Results of epidemiological models should be considered as guiding beacon instead of final destination.

\section{Keywords}

COVID-19; Transmission; Mathematical Models

In the recent past, the term modelling, prediction models and the probable number of cases is in everyone's thoughts as the entire globe is in mid of pandemic of new coronavirus, COVID-19. While country specific efforts are underway to control and 
limit the spread of the virus, isolation of the cases and quarantine the suspects, it is evident that there is still a lot of thing required in terms of

understanding the dynamics of infectious diseases and predicting the outbreaks. The ways in COVID-19 has become pandemic across the globe, a serious concern has been raised in predicting the further spread and more research will further help our understanding of infectious diseases that will influence our lives.

While basic and clinical researchers are working to improve diagnostics, vaccination and treatment aspects of COVID19, researchers from various domains having expertise in infectious disease modelling are trying to understand the overall

burden, need of hospital resources and impact of containment or mitigation on disease progression using mathematical models and simulations. Mathematical models are useful in hypothesis testing, assessing the best and worst scenarios, evaluating the impact of various policies as well as pharmaceutical and non-pharmaceutical interventions on disease outbreak, (1) Epidemiological models use available data from previous outbreaks and also the current outbreak to predict who might get infected, probable hot spots and high risk population which can be used to identify and plan most effective targeted pharmaceutical (vaccination) or non-pharmaceutical interventions (containment, mitigation or suppression) to limit the speed \& spread of the disease.

The use of the mathematical model in the study of infectious diseases is being envisaged as an insightful alternative to demanding needs of outbreak that are time intensive, high cost research and at times an option to replace ethically compromised research with complicated interpretation. While the ability of an accurately forecast disease patterns is crucial to ensure that the right resources are in place to handle outbreaks, many a times the prediction for same diseases under similar epidemiological conditions may vary a lot due to various reason (1). Presented here is a review published by various authors on COVID-19 scenario with specific reference to the Indian context.

To understand the review in the context, a brief about the commonly used concepts in mathematic models and types of models is necessary. There are three important epidemiological concepts needed to determine and understand the spread of an infectious disease and its transmission - Agent, Host and Environmental factors. The rate of transmission of any infectious disease may differ in different age groups and might vary with the respective incubation period. Besides this type and mode of transmission and the herd immunity are also known to govern the transmission of disease. $(2,3)$

Understanding of infectious diseases also requires knowledge of the various processes involved in hostpathogen interactions. Epidemiological process of disease transmission and individual host immunological response are two guiding principles of host-pathogen interactions. (4)

Modelling of host-pathogen interactions assist in determining key factors that may have a major impact on the outcome of an infection. In diseases like COVID-19, modelling is based on the interaction between the susceptible individuals and infected with in the population, while host dynamics is not given adequate importance. (4) Few other terminologies associated with infectious disease modelling are (a) infectivity or secondary attack rate, defined as the ratio of number infected and number of exposed individuals, (b) pathogenicity or illness rate, expressed as the ratio of number with symptoms and number infected individuals and (c) virulence defined as the ratio of number of severe/fatal cases and total number of cases.

\section{Domains of mathematical models}

Mathematical models work under various domains and the number of the domain in the model may differ from disease to disease. Most of the epidemiological modelling concept is based on compartment models which shows the infection status of individuals, where the population is supposed to move from one compartment to another with time and an individual is supposed to be in a single compartment at a given time. Few of the commonly used models are discussed below:-

a. Susceptible-Infectious-Recovered (SIR) model: In this model in order to emulate epidemics, population is classified as Susceptible (individual who never had any disease but are susceptible), Infectious or case (currently Infectious) and finally those who are Recovered from the infection. It is based on the relative magnitude 
whereby factoring an infected host who can potentially infect others before becoming Infectious. Hence, the total time spent in the infected state by an individual is considered a geometric random variable. It also assumes that when an infectious agent is removed from infected group or there is death of an infected case or if case recovers and develop immunity, hence will never be infected again. It assumes that the number of infected individuals tends to decrease over a period of time towards zero and will finally disappears from the network permanently. Thus, in SIR model, cumulative cases increases exponentially initially until there has been a sufficient decrease in the proportion susceptible, and the growth rate slows down. This is most widely used model and is applicable for diseases which are contracted by an individual only once in its lifetime and the outcome is either acquired lifelong immunity develop or death occurs as in case of mumps, measles, SARS, etc. An important drawback of SIR model is that it random effects cannot be included, specially at early stages of infection, with low prevalence of susceptible and infected individuals. This model is also unable to describe the spatial aspects of the spread of the disease. Moreover, in this modelling approach it is assumed that each individual has the same amount of contacts as every other individual. Stochastic version of SIR model is also available which deals with future course of the infection considering it is independent of the past, under the assumption of completely known present. (5, 6)

b. Susceptible-Exposed-Infectious-Recovered (SEIR): It is extended version of SIR model with a new compartment or group of Exposed being added, it is placed between those who are susceptible and those who are infectious. It refer to a condition when an individual is infected but not infectious, i.e. the disease remains in latent state. (7) If the agent burden becomes sufficiently high, the Exposed host may become Infectious and disease can be transmitted to another susceptible individual. When the Infectious individual no longer transmit infection due to immunity and is clear of the pathogen, he is termed to be recovered category. There is a thin demarcation between the domains of
Exposed-Infectious and Infectious-Recovered is not very distinct because of variability in responses between different individuals and variability in pathogen levels over the infectious period. (8)

c. Susceptible-Infectious- Recovered-Susceptible (SIRS): This model assumes that after recovery, the person becomes susceptible again as immunity wanes, i.e. recovered individuals possess only short-term immunity or no immunity. (3)

d. Susceptible- Infected (SI): This modelling approach assumes that an infected individual remains in this state for life long once infected and hence not very commonly used. In the early stages of an infection, when the count of infected cases is low, the SI and SIR models behave in a similar fashion as there is limited number of recovered individuals. (4)

e. Susceptible-Infectious-Susceptible (SIS): In this model, individuals moves across domain of Susceptible-Infected - Susceptible. Thus, assumes that only two states exist in infectious disease the infected individual, after recovery and becoming susceptible to infection again. Removal due to death or acquired immunization is not considered. Therefore, the number of infected individuals increases up to a stationary non zero constant value as observed in case of many disease like sexually transmitted infections, Vector borne disease etc. This model is based on assumptions like, different contagion probabilities between different pairs of people, probabilistic recovery from the disease and multiple stages of infection, with varying disease properties. (9)

\section{Material \& Methods}

\section{Literature search}

The search strategy used for the review was "Coronavirus" OR "COVID-19" OR "SARS-CoV-2" AND "Mathematical" OR "Predictive" AND "Model" AND "India". As the purpose was to gather all the available reports for the evidence synthesis, we opted for academic search using PubMed and Google search engines. Current review was conducted according to Preferred Reporting Items for Systematic Reviews and Meta-Analyses (PRISMA) guidance (10). We accessed the published literature, grey literature, new paper articles and print media interview focusing on Modelling with specific 
reference to Indian context from 1st February 2020

till date 10th April 2020, using the search terms "COVID-19 modelling" or "CORONA VIRUSE modelling" or "Predictive COVID-19and/or Corona". This enabled us with identification of grey literature, news reports and scientific peer-reviewed articles. For news reports the authors were also contacted in case of unclarity in the findings. We limited our search to article published in English language only and included articles published between 1st February, 2020 (as first case of India was reported on 30th January) to 10th April 2020 only. All the models published/reported from India were retrieved using above mentioned search strategies and were independently assessed for its reliability by two researchers. Any discordance found was resolve by discussion or opinion of third reviewer. The complete the landscape of information, we also searched for and included media reports, news channel bites, You Tube channels and blogs by individuals, universities focusing on pre decided search terms discussed above.

\section{Results and Discussion}

The key characteristics of the studies included in the review are summarized and presented as (Table 1). It specifically mentions the type of model used by the investigators, the core objectives for which the model has been developed and brief conclusions. Though we conducted data search for last three months, it was found that the predictive models reporting from Indian context have started publishing very recently (second week of March) due to relatively late onset of COVID outbreak in India as compared to other parts of the world. The review indicated mixture of approaches and study aims. We did scan for you tube channels, blogs and print media reports but they were largely based on the models presented in the table except the one which was widely quoted on NEWS channels but no supporting evidences could be retrieved supporting the claims. (24) Substantial number of studies undertook prediction of COVID spread and opted for a modelbased simulation exercises to predict potential cases of infection and fatality rate for broad range of time duration (short-term predictions and long-term trends). Most of the studies done in Indian context are in form of blogs or news articles and they are not peer reviewed by any other subject expert which is a gold standard of academic research.
According to the calculations projected by an epidemiological tool worst case and best-case scenario for India were predicted. (25) It stated that if all the preventive and management interventions are optimally utilized in India near about 15,000 people will be infected by COVID-19 with estimated deaths of around 300 . Whereas if the health system will not be able to implement the intervention and if the case fatality rate moves to $4 \%$, around 180 million positive cases and 5 million deaths will be observed as worst-case scenario. (25)

With increasing numbers of affected cases and emerging reports of better understanding and better anticipation of the future estimates from other countries another group of epidemiologists have started developing mathematical tools for predictions for effectiveness of various preventive and management strategies. First modelling was conducted to assess the impact of social distancing, three-week lockdown on and forecasted the disease spread under the influence of these factors. These factors were subsequently assessed by other investigators as well and numerous mathematical algorithms were developed to forecast magnitude of morbidity, impact of quarantine, different protocols of lockdown and social distancing, health system preparedness, required number of tests to replicate other best performing country models and potential use of non-pharmacological interventions. Some of these forecasting models have provided useful insights and assisted policy decisions for control of disease, however the models in current state suffers from some limitations.

\section{Conclusion}

- Majority of the models were designed to predict COVID spread, and claimed to be accurate, however they critically mentioned data gaps and need to adjust confounding variables such as effect of lockdown, risk factors and adherence to social distancing.

- Second largest group of studies assessed effect of lockdown and social distancing. Surprisingly in contrast to popular opinion that support lockdowns and social distancing, these models pointed out that lockdowns alone will be insufficient they should be accompanied by other effective measures such as active screening, other non-pharmacological interventions, effective hand-hygiene practices. 
- India has unique cultural, demographical, epidemiological and risk-factor profiling. The forecasting models needs to consider these population specific characteristics when developing contextual models. Failing to do so may lead to completely misleading predictions for the disease.

- The message of most epidemiological/mathematical models should be considered as qualitative in nature and more focus should be given on planning and prevention instead of highlighting quantitate numbers; disease burden and mortality.

However, findings from these models should be interpreted with caution due to following:

1. Majority of the models essentially needs population specific information (it's a novel infection and natural history of disease is still unknown) and in case of lack of accurate data the model may lead to over or underestimation.

2. Most of the models included an underlying RO 22.5 , but research from CDC, USA suggest it may be as high as 5.7 (95\% Cl: 3.8-8.9), it may lead to a scenario that all models were wrong. (26)

3. As reported earlier COVID-19 is mutating like any other virus, which strain is more prevalent in India is also matter of study as they differ in aggression. (27)

4. All the models assume that all the humans will be infected from the novel disease in absence of any immunity. However, data from South Korea suggests about $2.05 \%$ positive among total tested individuals till 10th April 2019. Indian COVID-19 testing is very selective and only high risk and their contact are tested with about $4.67 \%$ positive among total tested individuals till 10th April 2019. (28)

5. Results from various nations suggests virus is less infective (up to $80 \%$ less) in open spaces and may be more infectious in close environment and crowded places.

6. It was noted in most of clustered cases, people have either used shared toilet or are family members so only meeting from a distance may not infect anyone.

7. India has a unique place in terms of youngest population, malaria endemic and placed in the tropical region which may impact disease severity as well as spread.
8. All the models ignored age, cultural differences (Pranam or namaste in place of a hug), the habit of eating mostly at home, mostly rural population ( $>65 \%)$, less mobility in older adults while predicting morbidity and mortality.

9. COVID19 have an association with comorbidities, especially cardiovascular diseases, hypertension as well as diabetes, have high prevalence in older adults, age-sex-placedisease specific model may be more useful to predict COVID19 course in India.

10. All the models ignored the natural mortality.

11. As Hydroxychloroquine seems to be reducing severity as well as mortality in COVID19, and its metabolism is prolonged, being a malaria endemic country may play a role in disease progression and severity. (29)

\section{Limitation of the study}

As the COVID-19 outbreak in India is evolving and there has been rapid changes in the policies in Suspected Cases, Confirm cases, Policy of Isolation and Quarantine, PPE, Universalization of use of Mask, Personal Protective Equipment's and uncertainty in duration of lock down and the process of lifting lock down, the observations should be referred as on the available situation and analysis on 10th April 2020.

\section{Authors Contribution}

All authors have contributed equally.

\section{References}

1. Virulence 4:4, 295-306; May 15, 2013; c 2013 Landes Bioscience accessed on 3 April 2020

2. Dimitrov NB, Meyers LA. Mathematical approaches to infectious disease prediction and control. InRisk and optimization in an uncertain world 2010 Sep (pp. 125). INFORMS.

3. Piazza $\mathrm{NI}$, Wang $\mathrm{H}$. Bifurcation and sensitivity analysis of immunity duration in an epidemic model. International Journal of Numerical Analysis and Modelling, Series B, 4 (2), 179. 2013;202.

4. Siettos, Constantinos \& Russo, Lucia. (2013). Mathematical modeling of infectious disease dynamics. Virulence. 4. 10.4161/viru.24041.

5. Dimitrov NB, Meyers LA. Mathematical approaches to infectious disease prediction and control. InRisk and optimization in an uncertain world 2010 Sep (pp. 125). INFORMS.

6. Choisy M, Guégan JF, Rohani P. Mathematical modeling of infectious diseases dynamics. Encyclopedia of infectious diseases: modern methodologies. 2007:379. 
7. Masuda N, Holme P. Predicting and controlling infectious disease epidemics using temporal networks. F1000prime reports. 2013;5.

8. Keeling MJ, Rohani P. Modeling infectious diseases in humans and animals. Princeton University Press; 2011.

9. Barthélemy $M$, Barrat $A$, Pastor-Satorras $R$, Vespignani A. Dynamical patterns of epidemic outbreaks in complex heterogeneous networks. Journal of theoretical biology. 2005;235:275.

10. Moher D, Liberati A, Tetzlaff J, Altman DG, Altman D, Antes G, Atkins D, Barbour V, Barrowman N, Berlin JA, Clark J. Preferred reporting items for systematic reviews and meta-analyses: the PRISMA statement (Chinese edition). Journal of Chinese Integrative Medicine. 2009 Sep;7(9):889-96.

11. Mandal S, Bhatnagar T, Arinaminpathy N, et al. Prudent public health intervention strategies to control the coronavirus disease 2019 transmission in India: A mathematical model-based approach. The Indian journal of medical research. 2020.

12. Singh R, Adhikari R. Age-structured impact of social distancing on the COVID-19 epidemic in India. arXiv preprint arXiv:2003.12055. 2020.

13. ICMR initiates study to predict the rate of Covid-19 infections in India. Available from: https://economictimes.indiatimes.com/industry/hea Ithcare/biotech/healthcare/icmr-initiates-study-topredict-the-rate-of-covid-19-infections-inindia/articleshow/74768015.cms?from $=$ mdr. [Last accessed 26 March 2020].

14. Covid-19: Mathematicians, too, chip in to decode the pandemic. Available from: https://www.thehindubusinessline.com/news/scienc e/covid-19-mathematicians-too-chip-in-to-decodethe-pandemic/article31155268.ece\#. [Last accessed 26 March 2020].

15. Covid-19 rise and spread with specific predictions till 1st April for India and US. Available from: https://www.analyticsinsight.net/covid19-rise-andspread-with-specific-predictions-till-1st-april-forindia-and-us/. [Last accessed 30 March 2020].

16. Shrivastava SR, Shrivastava PS. Resorting to mathematical modelling approach to contain the coronavirus disease 2019 (COVID-19) outbreak. Journal of Acute Disease. 2020;1:49.

17. COVID-19 can only be fought at the grassroots with awareness: Jayaprakash Muliyil. Available from: https://www.cnbctv18.com/healthcare/covid-19can-onlybe-fought-atthegrassrootswith-awarenessjayaprakash-muliyil-5601541.htm. [Last accessed 5 April 2020].

18. Coronavirus: How many cases will India see? Here's one expert's best-case prediction. Available from: https://www.indiatoday.in/india/story/coronaviruscases-india-covid-19-ramanan-laxminarayan-

interview-1658087-2020-03-21. [Last accessed 26 March 2020].

19. Predictions and role of interventions for COVID-19 outbreak in India. Available from: https://medium.com/@covind_19/predictions-androle-of-interventions-for-covid-19-outbreak-in-india52903e2544e6. [Last accessed 26 March 2020].

20. Covid-19 India: State-level Estimates of Hospitalization Needs. Available from: https://cddep.org/wp-

content/uploads/2020/04/Covid.state.hosp.pdf. [Last accessed 5 April 2020].

21. The Viral Explosion: A District-Wise Projection Map For Covid-19 In India. Available from: https://swarajyamag.com/science/the-viralexplosion-a-district-wise-projection-map-for-covid19-in-india. [Last accessed 5 April 2020].

22. A prediction model for COVID-19. Available from: https://www.thehindu.com/opinion/op-ed/aprediction-model-for-covid-19/article31092695.ece. [Last accessed 25 March 2020].

23. Goli S, James KS. How much India detecting SARSCoV-2 Infections? A model-based estimation. medRxiv/2020/059014. 2020.

24. India missed the bus on testing. It should lock down now, 3 weeks later it wont work. Available from: https://www.youtube.com/watch?v=2HvAWGuiyfE. [Last accessed 10 April 2020].

25. Coronavirus India cases and deaths: Best or worst, this online epidemic calculator shows Covid-19 projections. Available from: https://www.indiatoday.in/technology/features/stor y/covid-19-cases-and-deaths-in-india-this-onlineepidemic-calculator-shows-all-projections-16606132020-03-28. [Last accessed 10 April 2020].

26. Sanche S, Lin YT, Xu C, Romero-Severson E, Hengartner N, Ke R. High Contagiousness and Rapid Spread of Severe Acute Respiratory Syndrome Coronavirus 2. Emerging infectious diseases. 2020;26.

27. Xiaolu Tang, Changcheng $\mathrm{Wu}$, Xiang $\mathrm{Li}$, et al. On the origin and continuing evolution of SARS-CoV-2, National Science Review. 2020. nwaa036.

28. The updates on COVID-19 in Korea as of 11 April. Available from: https://www.cdc.go.kr/board/board.es?mid=a30402 $000000 \&$ bid $=0030 \&$ act $=$ view $\&$ list_no=366810\&tag $=$ \&nPage=1. [Last accessed 11 April 2020].

29. Gustafsson LL, Lindstrom B, Grahnen A, Alvan G. Chloroquine excretion following malaria prophylaxis. British journal of clinical pharmacology. 1987 Aug;24(2):221-4 
TABLE 1 SUMMARY OF THE STUDIES INCLUDED IN THE REVIEW

\begin{tabular}{|c|c|c|c|c|c|c|}
\hline $\begin{array}{l}\text { Sr. } \\
\text { No }\end{array}$ & $\begin{array}{l}\text { Authors/So } \\
\text { urces }\end{array}$ & Title & Link & $\begin{array}{l}\text { Model } \\
\text { used }\end{array}$ & Objectives & Conclusions \\
\hline 1 & $\begin{array}{l}\text { Mandal et } \\
\text { al., } 2020 \\
(11)\end{array}$ & $\begin{array}{l}\text { Prudent public } \\
\text { health } \\
\text { intervention } \\
\text { strategies to } \\
\text { control the } \\
\text { coronavirus } \\
\text { disease } 2019 \\
\text { transmission } \\
\text { in India: A } \\
\text { mathematical } \\
\text { model-based } \\
\text { approach }\end{array}$ & $\begin{array}{l}\text { http://www.ijmr.or } \\
\text { g.in/preprintarticle. } \\
\underline{\text { asp?id=281325;typ }} \\
\underline{\mathrm{e}=0}\end{array}$ & SEIR model & $\begin{array}{l}\text { Possibility to } \\
\text { prevent, or delay, } \\
\text { the local outbreaks } \\
\text { of COVID-19 } \\
\text { through 1) } \\
\text { restrictions on } \\
\text { travel from abroad } \\
\text { 2) quarantine of } \\
\text { symptomatic } \\
\text { patients }\end{array}$ & $\begin{array}{l}\text { During initial phase } \\
\text { Port-of-entry-based } \\
\text { entry screening will } \\
\text { impart modest delay in } \\
\text { transmission. After } \\
\text { community } \\
\text { establishment of } \\
\text { infection, quarantine } \\
\text { will be an effective } \\
\text { strategy. }\end{array}$ \\
\hline 2 & $\begin{array}{l}\text { Singh and } \\
\text { Adhikari, } \\
2020 \text { (12) }\end{array}$ & $\begin{array}{l}\text { Age- } \\
\text { structured } \\
\text { impact of } \\
\text { social } \\
\text { distancing on } \\
\text { the COVID-19 } \\
\text { epidemic in } \\
\text { India }\end{array}$ & $\frac{\text { https://arxiv.org/pd }}{\underline{\text { f/2003.12055.pdf }}}$ & SIR model & $\begin{array}{l}\text { Age-structured SIR } \\
\text { model with } \\
\text { social contact } \\
\text { matrices to study } \\
\text { the progress of the } \\
\text { COVID-19 epidemic } \\
\text { in India. }\end{array}$ & $\begin{array}{l}\text { A three-week } \\
\text { lockdown is found } \\
\text { insufficient to prevent } \\
\text { a resurgence } \\
\text { and, instead, protocols } \\
\text { of sustained lockdown } \\
\text { with periodic } \\
\text { relaxation are } \\
\text { suggested. }\end{array}$ \\
\hline 3 & $\begin{array}{l}\text { Economic } \\
\text { Times, } \\
\text { March 23, } \\
2020 \text { (13) }\end{array}$ & $\begin{array}{l}\text { ICMR initiates } \\
\text { study to } \\
\text { predict the } \\
\text { rate of Covid- } \\
19 \text { infections } \\
\text { in India }\end{array}$ & $\begin{array}{l}\frac{\text { https://economicti }}{\text { mes.indiatimes.co }} \\
\frac{\mathrm{m} / \text { industry/healthc }}{\text { are/biotech/health }} \\
\frac{\text { care/icmr-initiates- }}{\text { study-to-predict- }} \\
\underline{\text { the-rate-of-covid- }} \\
\underline{\text { 19-infections-in- }} \\
\text { india/articleshow/7 } \\
\underline{4768015 . c m s ? f r o m} \\
=\text { mdr }\end{array}$ & $\begin{array}{l}\text { SEIR } \\
\text { Model }\end{array}$ & $\begin{array}{l}\text { To predict number } \\
\text { of cases India that } \\
\text { will be grappling } \\
\text { with in the next } \\
\text { few months. }\end{array}$ & $\begin{array}{l}\text { It states that the } \\
\text { results are yet to come }\end{array}$ \\
\hline 4 & $\begin{array}{l}\text { The } \\
\text { HinduBussi } \\
\text { nessLine, } \\
\text { March 23, } \\
2020 \text { (14) }\end{array}$ & $\begin{array}{l}\text { Covid-19: } \\
\text { Mathematicia } \\
\text { ns, too, chip in } \\
\text { to decode the } \\
\text { pandemic }\end{array}$ & $\begin{array}{l}\text { https://www.thehi } \\
\text { ndubusinessline.co } \\
\frac{\mathrm{m} / \text { news/science/co }}{\text { vid-19- }} \\
\text { mathematicians- } \\
\text { too-chip-in-to- } \\
\text { decode-the- } \\
\text { pandemic/article31 } \\
\text { 155268.ece\# }\end{array}$ & $\begin{array}{l}\text { Mathemati } \\
\text { cal } \\
\text { modelling }\end{array}$ & $\begin{array}{l}\text { To predict } 1 \text { ) the } \\
\text { number of Covid-19 } \\
\text { infections that can } \\
\text { be expected in a } \\
\text { country, region or a } \\
\text { city with and } \\
\text { without various } \\
\text { measures initiated } \\
\text { by the authorities } \\
\text { 2) Number of ICU } \\
\text { beds, ventilators } \\
\text { and other critical } \\
\text { pieces of health } \\
\text { infrastructure are } \\
\text { required to deal } \\
\text { with the problem }\end{array}$ & $\begin{array}{l}\text { Social distancing, } \\
\text { lockdowns, using the } \\
\text { mask and hand- } \\
\text { washing are very } \\
\text { important preventive } \\
\text { strategies and can } \\
\text { bring reproductive } \\
\text { number of virus to less } \\
\text { than } 1 .\end{array}$ \\
\hline 5 & $\begin{array}{l}\text { Analytics } \\
\text { Insights, }\end{array}$ & $\begin{array}{l}\text { Covid-19 rise } \\
\text { and spread } \\
\text { with specific }\end{array}$ & $\frac{\text { https://www.analyt }}{\frac{\text { icsinsight.net/covid }}{19-\text { rise-and-spread- }}}$ & $\begin{array}{l}\text { Third } \\
\text { degree } \\
\text { polynomial }\end{array}$ & $\begin{array}{l}\text { To predict COVID- } \\
19 \text { rise in India }\end{array}$ & $\begin{array}{l}\text { The model effectively } \\
\text { predicts cases COVID- } \\
19 \text { in India in }\end{array}$ \\
\hline
\end{tabular}



March 28,
2020 (15)
predictions till
1st April for
India and US
predictions-till-1st- april-for-india-and- us/
with-specific-

6 http://www.jadwe

b.org/article.asp?is

sn $=2221$ -

6189; year=2020; vol

ume $=9$; issue $=2$; spa

ge $=49$; epage $=50$; au

last=Shrivastava

disease 2019

(COVID-19)

outbreak
Mathemati

cal

modelling
To obtain precise estimate about the incubation period, case fatality ratio, infection fatality ratio and the serial interval immediate future.

However, lockdowns

and the weather

changes needs to be

taken into

consideration to

improve accuracy of

the model.

Mathematical

modelling provides

useful tool that

provides better

understanding and

better anticipation

of the future

estimates, though

more information on

health workers,

predisposing risk

factors, travellers and

households are

required.

India's lockdown

efforts may not

immediately show a

flattening of the curve, adding that sustained efforts for containment will be necessary

1) 300 million

infections mild

infections will occur 2)

10 million severe

infections will occur

and will happen within

a two or three-week

window, and will

require a lot of

intensive care 3)

Lockdown and social

distancing are

important measures

Predicted number of

affected cases based

on statistics of 4 cities

(most affected)

Group, And Role Of

https://medium.co

SIR model

Impact of

m/@covind 19/pre

interventions on

COVID spread

of-interventions-

for-covid-19-

outbreak-in-india-

52903e2544e6

10 Tseng et

al., 2020

https://cddep.org/

wp-

India: State-

level

content/uploads/2

Estimates of

020/04/Covid.state .hosp.pdf

\section{Statistical}

modelling

\section{To determine}

hospitalization

capacity in each

state for different

assumed incidence
In sufficient data to

assess impact of

lockdown on

hospitalization needs 


\begin{tabular}{|c|c|c|c|c|c|c|}
\hline \multicolumn{6}{|c|}{ VDIAN JOURNAL OF } & \multirow{2}{*}{ [Running title] | Author $\mathrm{A}$ et al } \\
\hline & & $\begin{array}{l}\text { Hospitalizatio } \\
\text { n Needs }\end{array}$ & & & $\begin{array}{l}\text { levels } \\
\text { of Covid-19 }\end{array}$ & \\
\hline 11 & $\begin{array}{l}\text { Kaushal et } \\
\text { al., April 1, } \\
202(21)\end{array}$ & $\begin{array}{l}\text { The Viral } \\
\text { Explosion: A } \\
\text { District-Wise } \\
\text { Projection } \\
\text { Map For } \\
\text { Covid-19 In } \\
\text { India }\end{array}$ & $\begin{array}{l}\text { https://swarajyama } \\
\text { g.com/science/the- } \\
\text { viral-explosion-a- } \\
\text { district-wise- } \\
\text { projection-map-for- } \\
\text { covid-19-in-india }\end{array}$ & $\begin{array}{l}\text { Heuristic } \\
\text { predictive } \\
\text { model }\end{array}$ & $\begin{array}{l}\text { To provide a } \\
\text { detailed state-wise } \\
\text { projection map for } \\
\text { India }\end{array}$ & $\begin{array}{l}\text { For many states, } \\
\text { lockdown has } \\
\text { noticeably reduced the } \\
\text { expected growth rate. } \\
\text { As predicted, the } \\
\text { different Indian states } \\
\text { are seeing different } \\
\text { parts of the pandemic } \\
\text { wave currently. The } \\
\text { pandemic has grown as } \\
\text { predicted for several of } \\
\text { the Indian states. } \\
\text { Uncertainties in } \\
\text { reported infections to } \\
\text { fatalities has a wide } \\
\text { variation across states. } \\
\text { Recommendation: } \\
\text { States showing greater } \\
\text { than } 4 \text { per cent fatality } \\
\text { should invest in more } \\
\text { testing. }\end{array}$ \\
\hline 12 & $\begin{array}{l}\text { Atanu } \\
\text { Biswas, } \\
\text { March 17, } \\
2020(22)\end{array}$ & $\begin{array}{l}\text { A prediction } \\
\text { model for } \\
\text { COVID-19 }\end{array}$ & $\begin{array}{l}\text { https://www.thehi } \\
\text { ndu.com/opinion/o } \\
\text { p-ed/a-prediction- } \\
\text { model-for-covid- } \\
\underline{\text { 19/article31092695 }} \\
\text {.ece }\end{array}$ & $\begin{array}{l}\text { SEIR } \\
\text { (Susceptibl } \\
\text { e-Exposed- } \\
\text { Infectious- } \\
\text { Resistant) } \\
\text { model }\end{array}$ & $\begin{array}{l}\text { To predict the cases } \\
\text { of COVID-19 }\end{array}$ & $\begin{array}{l}\text { Basic reproductive } \\
\text { numbers (BRN) value } \\
\text { for India is unknown } \\
\text { due to inadequate data } \\
\text { so far. However, it can } \\
\text { be kept small by } \\
\text { isolating patients and } \\
\text { controlling infection by } \\
\text { extensive checking at } \\
\text { airports and other } \\
\text { important places. }\end{array}$ \\
\hline 13 & $\begin{array}{l}\text { Goli et al., } \\
2020(23)\end{array}$ & $\begin{array}{l}\text { How much } \\
\text { India } \\
\text { detecting } \\
\text { SARS-CoV-2 } \\
\text { Infections? A } \\
\text { model-based } \\
\text { estimation }\end{array}$ & & $\begin{array}{l}\text { Bommer } \\
\text { and } \\
\text { Vollmer } \\
\text { model }\end{array}$ & $\begin{array}{l}\text { To assess the } \\
\text { quality of } \\
\text { official case records }\end{array}$ & $\begin{array}{l}\text { Advocated population- } \\
\text { level random } \\
\text { testing to assess the } \\
\text { prevalence of the } \\
\text { infection. }\end{array}$ \\
\hline
\end{tabular}

